\title{
Corruption and Common People in Petroleum Business - A Sociological Study
}

[With special reference to chikkamagalore District-Karnataka state]

\section{R.Devananda}

Research Scholar

Bharathiar University,

Coimbatore, Tamilnadu

Email:devanandar59@gmail.com
Dr. G. D Narayana

Research Supervisor

Dept. of PG studies and Research Sociology,

Bharathiar University,

Coimbatore, Tamilnadu
Abstract

The word petroleum comes from Greek. The term frequently used to refer to mineral oils produced by distillation from mined organic solids such as cannel coal and refined oils produced from them, they are derived from crude oil as it is processed in oil refineries, they are collection of well defined pure chemical compounds, petroleum products are complex mixtures.

Petroleum products are very essential products for transportation, heating, electricity generation, asphalt and road oil. They are used to make chemicals, plastics and synthetic materials which we are using in daily life. About $74 \%$ of the 6.89 billion barrels of petroleum that we used in 2013 were gasoline, heating oil/diesel fuel and jet fuel.
Reference to this paper should be made as

follows:

R.Devananda, Dr. G. D Narayana

Corruption and Common People in Petroleum Business A Sociological Study

Journal Global Values

Vol. XI, No.I

Article No.08

pp.57-66

http://anubooks.com/

?page_id $=6195$

https://doi.org/

$10.31995 /$

jgv.2020.v11i01.008 
Corruption and Common People in Petroleum Business -A Sociological Study

R.Devananda, Dr. G. D Narayana

\section{Introduction}

\section{Petrol Stations in India}

According to 20 January 2015 there are 51,870 petrol pumps are working India.According to 20 January 2015 there are 2500 petrol pumps working in Karnataka state.

Those obtained from crude oil and natural gas processing, including (among many others) asphalts, automotive gasoline's, aviation gasoline's, fuel oils, kerosene, liquefied petroleum gas (LPG), lubricants, naphtha's, andwaxes.

India is the second most populous country in the world, with over 1.277 billion people (2015), more than a sixth of the world's population. Already containing $17.5 \%$ of the world's population, India is projected to be the worlds by 2022, surpassing China, its population reaching 1.6 billion by 2050.[5][6] Its population growth rate is $1.2 \%$, ranking 94th in the world in 2013. The Indian population had reached the billion mark by 1998 .

\section{Corruption}

The noun corruption comes from Latin.

Corruption means a putrid matter, bribery, impurity.

\section{The simplest definition is}

Corruption is the misuse of public power (by elected politician or appointed civil servant) for private gain. In order to ensure that not only public corruption but also private corruption between individuals and businesses could be covered by the same simple definition: Corruption is the misuse of entrusted power (by heritage, education, marriage, election, appointment or whatever else) for private gain. This broader definition covers not only the politician and the public servant, but also the CEO and CFO of a company, the notary public, the team leader at a workplace, the administrator or admissions-officer to a private school or hospital, the coach of a soccer team, etcetera. A much more difficult, scientific definition for the concept 'corruption' was developed by professor (emeritus) Dr. Petrus van Duyne

$$
\text { OR }
$$

Corruption can be defined as spiritual or moral impurity or deviation from an ideal. Corruption may include many activities including bribery and embezzlement. Economic insecurity, high rates of income tax, meager salary, and emergence the very presence of black money. Imbalances on socio-economic modernization are the major causes of corruption. The rapid growth of the practice of corruption should be controlled or eradication. India has implemented certain measures to eradicate corruption such as the legislative measures. 
Common people means: people in general

\section{Public life}

Public is derived from the Latin word poplicus, meaning "pertaining to the people" but is also related to the Latin word pubes. Meaning "adult." The public life was originally understood as an arena for people who had moved beyond childhood into adulthood and were ready to take care of themselves and help take care of others. I learned this in Parker Palmer's new book, "Healing the Heart of Democracy,"

\section{Objectives}

- To Analyses thecorruption factor in common people in petroleumbusiness.

- To search the ways to eradicate the corruption.

\section{Hypothesis}

- At the present scenario corruption plays an important rolewith common people in petroleum business.

\section{Importance of the study}

This study has an importance to known how the corruption plays with common people in petroleum business. Has not been studied in earlier days. So it gains importance.

\section{Methodology}

In this study we have used simple random sampling method on selected 50 respondents. We have used direct interview method for the collection of information by respondents. Who are working in petroleum bunks, business? And also used primary and secondary sources to collect the data with developmental perspective.

\section{Sources of information}

1) Primary resources:- To collect the primary information I used self prepared inter schedule on corruption in public life and measures for its eradication with common people.

2) Secondary resources:-we have collected information from Articles, journals, library, news papers and websites.

\section{Theoretical perspectives}

We used developmental perspective for thisstudy.

\section{Topographical Features of the Study}

Chikkamagalore is a district in the South Indian state of Karnataka. Coffee was first cultivated in India in Chikkamagalore. The mountains in Chikkamagalore which are a part of the Western Ghats are the source of rivers like Tunga and Bhadra. Area. • Total, 7,201 km2 (2,780 sq mi). Population(2001). Total, 1,139,104. 
Corruption and Common People in Petroleum Business -A Sociological Study

R.Devananda, Dr. G. D Narayana

- Density, 158.19/km2. Chikkamagalore dist., will come under the famous western guhts area. Chikkamagalore dist., famous for Coffee, Tea, Aracanut, coconut, Cardamom, Rubber plantation crops, commercial crops and food crops also.

It is also famous for tourism sports like Dattapita, Mullaiyana giri, Kallatthigiri, Kemmanna gundi, Amruthapura temple and so on. Information regarding chikkamagalore dist., as on today. There are BPC - 18, HPC-24, IOC-30, Reliance02, SR-01 total 75 bunks.

\section{Data Analysis}

The data collected by using all the research methods, and others sources are analyzed by essential statistical techniques by using analysis of data research report. The data was collected on structural development perspective.

Table. 1 Personal Profile of the Respondens

\begin{tabular}{|c|c|c|c|c|c|c|c|}
\hline SL & \multicolumn{7}{|c|}{ Personal profile of the Respondents } \\
\hline \multirow{2}{*}{1} & \multirow{2}{*}{ Age } & \multicolumn{2}{|l|}{$18-28$} & $29-39$ & $40-50$ & \multicolumn{2}{|r|}{$51+$} \\
\hline & & \multicolumn{2}{|l|}{20} & 18 & 02 & \multicolumn{2}{|r|}{10} \\
\hline \multirow{2}{*}{2} & \multirow{2}{*}{ Gender } & \multicolumn{4}{|c|}{ Male } & \multicolumn{2}{|c|}{ Female } \\
\hline & & \multicolumn{4}{|c|}{30} & \multicolumn{2}{|c|}{20} \\
\hline \multirow{2}{*}{3} & \multirow{2}{*}{ Caste } & $\mathrm{SC}$ & ST & \multicolumn{2}{|r|}{$\mathrm{OBC}$} & & Others \\
\hline & & 08 & 09 & \multicolumn{2}{|r|}{18} & & 05 \\
\hline \multirow{2}{*}{4} & \multirow{2}{*}{ Religion } & Hindu & \multicolumn{3}{|c|}{ Christian } & & Muslim \\
\hline & & 40 & \multicolumn{3}{|c|}{04} & & 06 \\
\hline \multirow[t]{2}{*}{5} & \multirow[t]{2}{*}{ Education } & Illiterates & \multicolumn{2}{|c|}{$\begin{array}{c}\text { Primary } \\
\text { education }\end{array}$} & \multicolumn{2}{|c|}{$\begin{array}{l}\text { Secondary } \\
\text { education }\end{array}$} & Higher education \\
\hline & & 02 & \multicolumn{2}{|r|}{22} & \multicolumn{2}{|l|}{21} & 05 \\
\hline \multirow[t]{2}{*}{6} & \multirow{2}{*}{$\begin{array}{l}\text { Monthly } \\
\text { Income }\end{array}$} & $\begin{array}{l}5000 \text { to } \\
8000\end{array}$ & \multicolumn{2}{|c|}{8001 to 11000} & \multicolumn{2}{|l|}{$\begin{array}{c}11001 \text { to } \\
12000\end{array}$} & $12001+$ above \\
\hline & & 18 & & 23 & 5 & & 4 \\
\hline \multirow{2}{*}{7} & \multirow{2}{*}{ Marriage } & Married & & achelor & \multicolumn{2}{|l|}{ Widow } & \\
\hline & & 30 & & 16 & 4 & & \\
\hline \multirow{2}{*}{8} & Family & Joint & & uclear & & & \\
\hline & Family & 02 & & 48 & & & \\
\hline
\end{tabular}

In demographic information age, gender, education qualification, , marital status, income size type of family etc, are various information's are followings

- Age:Age is the important factor at the time of interviewee because if the respondents are below 18 years age there will be considered as minors. 
They are not eligible into any contract according to Indian contract act1872.

- Gender

We interviewed $60 \%$ of the male respondents. $40 \%$ of the female respondents.

- Cast

At the time of research in India cast plays a important role even though India is secular state.

$\circ$ We interviewed $16 \% \mathrm{SC}, 18 \% \mathrm{ST}, 36 \% \mathrm{OBC}$ and others $10 \%$.

\section{- Religion}

India is the mother land of several religions. Even though its. secular state all the statistics are collected on the basis of religion like Hindu, Muslim, Christian, Jains, Parasis, Buddhists, siks and so on.

○ We interviewed Hindus $76 \%$, Christians $10 \%$, and Muslim $14 \%$.

\section{- Education}

Education plays in important role in India. Majority of the respondents are literates. $04 \%$ of respondents are illiterates, $44 \%$ respondents are educated up to primary,and $42 \%$ of respondents studied up to secondary education and $10 \%$ of respondents finished their higher education.

- Monthly Income

$36 \%$ of respondents are earning 5000 to $8000 \mathrm{rs}, 46 \%$ of respondents are earning 8001 to 11000 rs. $10 \%$ of respondents are earning 11001 to 12000 rs, $08 \%$ of respondents are earning $12000 \mathrm{rs}$, and above.

- Marriage

$60 \%$ of respondents are married. $32 \%$ of respondents are Bachelor. $08 \%$ of respondents are widows.

- Family

$04 \%$ of respondents are living in Joint family. $96 \%$ of respondents are living in Nuclear family.

Thematic Analysis Of The Study

\begin{tabular}{|c|l|c|c|}
\hline $\begin{array}{c}\text { Sl. } \\
\text { No. }\end{array}$ & \multicolumn{1}{|c|}{ Particulars } & Yes & No \\
\hline 01 & Corruption is a social evil & $100 \%$ & 00 \\
\hline 02 & Corruption is supported by all class people & $90 \%$ & $10 \%$ \\
\hline 03 & Is there corruption in grama panchayath admini stration & $80 \%$ & $20 \%$ \\
\hline 04 & Is there corruption in taluk panchayath administration & $75 \%$ & $25 \%$ \\
\hline 05 & Is there corruption in Zilla panchayath administration & $72 \%$ & $28 \%$ \\
\hline
\end{tabular}


Corruption and Common People in Petroleum Business -A Sociological Study R.Devananda, Dr. G. D Narayana

\begin{tabular}{|c|l|c|c|}
\hline 06 & Is there corruption in State government administration & $70 \%$ & $30 \%$ \\
\hline 07 & Are you support corruption? & $15 \%$ & $85 \%$ \\
\hline 08 & Are you affected by corruption? & $90 \%$ & $10 \%$ \\
\hline 09 & Are you fighting for the eradication of corruption? & $50 \%$ & $50 \%$ \\
\hline 10 & $\begin{array}{l}\text { Are you using petrol eum products for other than the } \\
\text { proposed purpose only. }\end{array}$ & $90 \%$ & $10 \%$ \\
\hline 11 & Are you using LPG cylinder for cocking purpose only. & $90 \%$ & $10 \%$ \\
\hline 12 & $\begin{array}{l}\text { Are you usingkerosene for other than cooking and } \\
\text { lighting purpose only? }\end{array}$ & $80 \%$ & $20 \%$ \\
\hline 13 & $\begin{array}{l}\text { Are you receiving the petrol and diesel from retail } \\
\text { outlets only. }\end{array}$ & $95 \%$ & $05 \%$ \\
\hline 14 & Are you using the subside properly. & $90 \%$ & $10 \%$ \\
\hline 15 & $\begin{array}{l}\text { Are you assisted by police department for illegal } \\
\text { petrol eum products business? }\end{array}$ & $10 \%$ & $90 \%$ \\
\hline 16 & $\begin{array}{l}\text { Are you assisted by Local authorities for illegal } \\
\text { petroleum products business? }\end{array}$ & $05 \%$ & $95 \%$ \\
\hline 17 & $\begin{array}{l}\text { Are you aware of dare consequences of storage of } \\
\text { petrol eum products without proper protection? }\end{array}$ & $90 \%$ & $10 \%$ \\
\hline 18 & $\begin{array}{l}\text { Are you feel the presence of oil mafia in petroleum } \\
\text { products business }\end{array}$ & $08 \%$ & $92 \%$ \\
\hline 19 & $\begin{array}{l}\text { Are you penalized by any government authority for } \\
\text { illegal petroleum products business so for. }\end{array}$ & 00 & $100 \%$ \\
\hline
\end{tabular}

\section{Corruption is a social evil}

In my interview all the respondents accepted that corruption is a social evil. It is from generations. It may be in cash or kind. It may be due to the circumstances in which respondent is living. In present people have no fear about corruption and its effects?

\section{Corruption is supported by all class people}

$90 \%$ of the respondents agrees, $10 \%$ disagrees. Corruption is supported when the things are not getting done by law full means.

\section{Corruption in grama panchayath administration}

$80 \%$ of the respondents agrees, $20 \%$ disagrees. Corruption in grama panchayath. At the village level people are not aware of laws and their fundamental rights and dutiesand facilities given by the concerned government for people welfare.

\section{Corruption in Taluk panchayath administration}

$75 \%$ of the respondents agrees, $25 \%$ disagrees. Corruption in Taluk panchayath. At the Taluk level people are educated about the laws and their fundamental rights and duties and facilities given by the concerned government for people welfare.

\section{Corruption in Zilla panchayath administration}

$72 \%$ of the respondents agrees, $28 \%$ disagrees. Corruption in Zilla 
panchayath. At the Zilla panchayath level people are aware of laws and regulations and government facilities.

\section{Corruption in State government administration}

$70 \%$ of the respondents agree, 30\% disagrees. Corruption in State government.In recent days the personnel of government are not caring for laws, disciplinary actions and departmental enquiries. Because of the interference of politicians, interference of cast, mussel and money power.

\section{Support corruption}

$15 \%$ of the respondents agrees, $85 \%$ disagrees. Because people want to get done their works immediately without any hurdles to achieve their short term goals.

\section{Effected by corruption}

$90 \%$ of the respondents agrees, $10 \%$ disagrees. Because people feel their works are not getting done well in time without paying bribe. Bribe is a common factor which motivate the government personnel to work for people welfare.

\section{Are you fight for the eradication of corruption}

$50 \%$ of the respondents agrees, $50 \%$ disagrees. $50 \%$ of the respondents are ready to fight against corruption on their own decision and the seek others co-operation for this purpose. They are optimistic.

$50 \%$ of the respondents feel to fight against corruption is not an easy joke. It brings presser on people who want to fight against corruption. And they are not ready to bare rick. They are pessimistic.

\section{Petroleum products for other than the proposed purpose}

$90 \%$ of the respondents use the petroleum products for the proposed purpose, and they use recommended fuel only for their vehicles. 10\% of the respondents are not using petroleum products for the proposed purpose. Eg. For LPG vehicles they use cooking gas. This creates the problem for the vehicle engine. Cooking gas generates more heat than the LPG gas. Cooking gas is meant for cooking purpose only. At the time of filling the cooking gas to their vehicle they bribe the authorities who want to check the malpractice like police department and food and civil supply's department. They use subsidized cooking cylinders for commercial purposes like hotel and welding business.

\section{Using LPG cylinder for cocking purpose}

$90 \%$ of the respondents agree, $10 \%$ of the respondents disagree. $90 \%$ of the respondents use LPG cylinders for the cooking purpose only. Because they are bound by the system, they don't want to miss use the cooking fuel. $10 \%$ of the 
Corruption and Common People in Petroleum Business -A Sociological Study

R.Devananda, Dr. G. D Narayana

respondents use LPG cooking cylinders for their gas vehicles, and they refill the gas stows also for lighting purpose.

\section{Use of kerosene for other thancooking and lighting purpose only}

$80 \%$ of the respondents agree, $20 \%$ disagrees. $80 \%$ of the BPL card holders and Anthyodaya card holders will use kerosene for cooking and lighting purpose only. $20 \%$ of the respondents sell their kerosene for black market which is used to fuel the Lorries and trucks along with the diesel.

\section{Petrol and diesel from retail out lets}

$95 \%$ of the respondents agree, $05 \%$ disagrees. $95 \%$ of the respondents are receiving petrol and diesel in the retail out lets only for their vehicles and for their utility. $05 \%$ of the respondents receive petrol and diesel by road side shops which are illegally selling petrol and diesel by bribing the local concerned authorities. This will creates fire accidents often and oftendamaging the life and property.

\section{Using the subside properly}

$90 \%$ of the respondents agrees, $10 \%$ disagrees. The union government is providing sufficientsubsidy to cooking gas, kerosene and fertilizers. $90 \%$ respondents are utilizing properly and $10 \%$ of the respondents are not utilizing the subsidies properly. So the union government of India is transferring the subsides to the beneficiary bank accounts only. Which will reach the needy person.

\section{Illegal Assistance by government department for petroleum products business \\ $10 \%$ of the respondents agrees, $90 \%$ disagrees. At the time of interview the} respondents explains how the police department supports illegal petroleum products business by receiving bribe. So times after receiving bribe they also book the cases under essential commodities act $-1955.90 \%$ of the respondents are disagrees the police supports.

\section{Assisted by Local authorities for illegal petroleum products business}

$05 \%$ of the respondents agree, $95 \%$ disagrees. Without the support of local authorities no illegal business can be carried out. So with the support of local authorities only they will conduct illegal petroleum product (Petrol, Diesel, Lubricants, Kerosene, Naphtha, Spirit and etc.) business. 95\% of the respondents disagrees the local authorities support.

17. Aware of dare consequences of storage of petroleum products without proper protection

$90 \%$ of the respondents agree, $10 \%$ disagrees. $90 \%$ of the respondents know the dare consequences of unscientific storage of petroleum products. $10 \%$ of 
the respondents are unaware of dare consequences of unscientific storage of petroleum products. At the time of illegal cooking gas refilling some fire accidents took place and several people lost their life and property. Ordinary LPG cooking gas is compressed in $14 \mathrm{~kg}$. Cylinder its original size is 270 times of the cylinder size. At the time of illegal storage of petroleum products caused major fire accidents damaging the life and property.

\section{Presence of oil mafia in petroleum products business}

$08 \%$ of the respondents agree, $92 \%$ disagrees. $08 \%$ of the respondents feel the Presence of oil mafia exploration point to customer point all over the world. For example one news reportedby international English news channel aljajira nearly 8500 trucks of petroleum products are smuggling every day, more than 8,500 tanker trucks are implicated in the trafficking of petrol by the Islamic Emirate, a long column transporting more than 200,000 tons of petrol into Turkey. The Russian generals presented a map showing the three main routes by which the IE smuggles petrol from Syria and Iraq into Turkey.92\% disagrees.

\section{Penalized by any government authority for illegal petroleum products business so for}

$01 \%$ of the respondents agrees, $99 \%$ disagrees. For illegal petroleum products business only one percent is penalized. $99 \%$ of the illegal petroleum products business is not penalized. Because of the political power, muzzle power, money power and by the role of corruption in all walks of life.

\section{Findings}

$>$ Majority of respondents are suffering from corruption in illegal petroleum business.

$>$ Respondents want to control the corruption and to eradicate corruption in illegal petroleum business.

\section{Conformation of Hypotheses}

By above all studies and statics we can say that rampant corruption is playing a major role in illegal petroleum business with common people.

\section{Suggestions}

I suggest the effective measures should be taken by the local authorities and the concerned government and departments to control corruption in illegal petroleum business which is affecting the common people.

\section{Conclusions}

For the corruption in public life and measures for its eradication in common 
Corruption and Common People in Petroleum Business -A Sociological Study

R.Devananda, Dr. G. D Narayana

people is very important. We should educate common people towards the corruption and its effects on the society and we have to tell them the masseurs for its eradication by changing common people mind set and attitude not blaming the darkness. We must put a candle with our own effort.

\section{References}

01. Petroleum Wikipedia

02. Hydrocarbons Education and Research Society.

03. Voltaire Network of Hong Kong

04. Aljazeera English News Channel.

05. News paper and Magazine. 